\title{
Canopy volume and application rate interaction on spray deposition for different phenological stages of coffee crop
}

\author{
Thales Cassemiro Alves ${ }^{1 *}$ (iD), João Paulo Arantes Rodrigues da Cunha1 ${ }^{(i D}$, Guilherme Sousa Alves ${ }^{2}$ (iD), \\ Sérgio Macedo Silva ${ }^{3}$ iD, Ernane Miranda Lemes ${ }^{1}$ iD
}

${ }^{1}$ Universidade Federal de Uberlândia/UFU, Instituto de Ciências Agrárias/ICIAG, Uberlândia, MG, Brasil

${ }^{2}$ Universidade de Nebraska, Lincoln, Nortene, NE, Estados Unidos

${ }^{3}$ Universidade Federal dos Vales do Jequitinhonha e Mucuri/UFVJM, Instituto de Ciências Agrárias/IAC, Unaí, MG, Brasil

Contact authors: thalescalves@hotmail.com

Received in June 19, 2020 and August 17, 2020

\section{ABSTRACT}

Coffee plants (Coffea arabica L.) present dense foliage that obstruct the entering of pesticides inside the plant canopy uniformly. Adjust the application rate concerning the plant canopy volume can be a way to make the pesticide applications more efficient. The objective of this study was to evaluate the deposition of spray solution on coffee leaves with different volumes of plant canopy and different application rates; additionally, to determine the specific volume indexes for different coffee phenological stages. The studies of coffee leaf deposition were performed on commercial fields of $C$. arabica - Topázio MG 1190 and Catuaí Vermelho IAC 99 cultivars, in different months. Three volumes of vegetation ranging from 8.572 to $16.200 \mathrm{~m}^{3}$ ha $^{-1}$ - obtained from the calculation of tree-row volume (TRV) performed in 20 plants - and five application rates $\left(200,300,400,600\right.$ and $\left.^{2} 800 \mathrm{~L} \mathrm{ha}^{-1}\right)$ and in each phenological stage (maturation, post-harvest, grain filling) were evaluated in a randomized block design with five replications. A bright blue marker was added to the spray solution to be detected by spectrophotometry in order to study the spray deposition and losses to the soil. After the treatment applications, ten coffee leaves corresponding to the 1st pair of leaf from an orthotropic branch of each third of the coffee plant (upper, middle, lower) were randomly collected. Petri dishes were used to evaluate the losses to the soil. The TRV and leaf density should be considered together in the definition of the application rate for coffee protection. It is also possible to reduce the application rate to values close to $200 \mathrm{~L} \mathrm{ha}^{-1}$. The volume indexes for each coffee phenological stage were defined for proper canopy wetting and low losses to the soil.

Key words: Coffea arabica L.; Spray losses to the soil; Spray volume; Tree-row volume; Volume index.

\section{INTRODUCTION}

Coffee is one of the leading agricultural products in Brazil, which is the world largest coffee producer and exporter (Copetti; Cornel, 2020). The Brazilian coffee production is from two main species: Coffea arabica Linnaeus and Coffea canephora Pierre ex Froehner (Vitória et al., 2018). Due to a sizeable territorial extension and diverse climatic conditions, Brazil presents multiple regions appropriate for coffee production, providing specific characteristics from each locality of cultivation (Gitirana Neto et al., 2016).

The diverse conditions found for coffee production indicate the need for differentiated crop managements (Ferreira; Leite; Lasmar, 2013). Therefore, the techniques of pesticide application must be used correctly, so that the active ingredient is deposited on the biological targets at the most appropriate time, in the correct amount, and with minimal losses (Cunha; Gitirana Neto; Bueno, 2011). In this context, it is necessary to know the spraying equipment and the plant architecture to obtain maximum efficiency (Alves; Cunha, 2014).

The spray application rates in tree crops are usually high in order to compensate for the losses by exo-drift and endo-drift, and for the active product to reach targets that are difficult to access (Tachibana; Antuniassi, 2008). The rates used in the coffee areas vary, in general, between 400 and $800 \mathrm{~L} \mathrm{ha}^{-1}$, reaching up to $1000 \mathrm{~L} \mathrm{ha}^{-1}$, regardless of the volume of plant foliage (Matiello et al., 2010). Therefore, this rate must be adjusted to allow satisfactory leaf wetness of the plant canopy with a minimum of loss by runoff into the ground (Miranda et al., 2012).

An alternative to improve the pesticide application in coffee plants is the TRV methodology - Tree-Row Volume (plant canopy volume) - developed by Byers, Hickey and Hill (1971) and introduced by Sutton and Unrath (1988). This method presents good results when used in the calibration of hydro-pneumatic sprayers (airblast) for applications in tree crops (Chen et al., 2013; Gil et al., 2007). In grapevines, the adoption of this method resulted in the reduction of pesticide uses in up to $57 \%$, maintaining the spray coverage and similar penetration to the conventional spraying (Gil et al., 2007). In the case of tomato crop, this reduction can reach to $30 \%$ (Sánchez-Hermosilla et al., 2013).

The TRV method is based on the measurement of the canopy volume and the use of volume indexes (VI) to determine the appropriate application rate in each situation. This method has been successfully used in fruit crops throughout Europe (Miranda-Fuentes et al., 2016). In Brazil, the TRV method is scarcely used. In citrus, some studies have already been conducted (Scapin et al., 2015; Silva Júnior et al., 
2016), showing the potential of the TRV methodology. General recommendations of VI used in Europe, range between 10 and 125 litres of spray solution to every $1.000 \mathrm{~m}^{3}$ of vegetation (Minguela; Cunha, 2010).

In coffee, there is little information and limitations regarding the adjustment of VI's due to the variation in the volume of plant foliage. This variation is due to several factors, such as defoliation by mechanized harvest and plant age (Santinato et al. 2015), insect infestation and pathogenic microorganisms (Matiello et al., 2010), pruning (Nascimento; Spehar; Sandri, 2014) and seasonal variations of water availability and temperature (Emilio et al., 2008). These variations result in changes in leaf density directly influencing the spray efficiency, especially, regarding the penetration, distribution and deposition of active ingredient in the plant canopy (Silva; Cunha; Nomelini, 2014).

Thus, the objective of this study was to evaluate the spray deposition on leaves in the coffee canopy and the losses to the soil proportionate for different application rates in different canopy volumes at different coffee phenological stages. This study also aimed to determine the specific volume indexes for coffee crop cultivation.

\section{MATERIAL AND METHODS}

The experiment was conducted in the coffee study area (Fazenda Glória) of the Federal University of Uberlândia, in Uberlândia, Brazil. The area is in a Cerrado region (Savanahlike biome), located at 912 meters above sea level and at the coordinates: $18^{\circ} 58^{\prime} 52^{\prime \prime}$ S latitude and 48 $12^{\circ} 24^{\prime \prime} \mathrm{W}$ longitude. According to the Köppen and Geiger (1928) classification, the climate of the region is Aw type (hot, humid summers with cold, dry winters). The area is slightly undulated; the soil is of clay texture and classified as a dystrophic red latosol (EMBRAPA, 2013).

The spray deposition on leaves and losses to the soil were evaluated in three coffee canopy volumes (three areas) calculated using 20 plants from different plots. Plant height, the width of the canopy thirds (lower, middle, upper) and the space between planting lines were collected with the aid of a metallic tape (Byers; Hickey; Hill, 1971) (Equation 1).

$$
T R V=\frac{H \times L \times 10000}{D}
$$

where:

TRV: tree-row volume $\left(\mathrm{m}^{3} \mathrm{ha}^{-1}\right)$;

$\mathrm{H}$ : plant height (m);

L: average width of the plant third (m); and,

D: distance between planting lines (m).

The experiment was repeated in three coffee phenological stages of development (maturing, post-harvest of fruits and grain filling), in May, July and December, respectively (Table 1). The coffee plants were spaced at $3.5 \mathrm{~m}$ between rows by $0.7 \mathrm{~m}$ between plants.

The experiments were set as a randomized complete block design, with five replications. Each plot consisted of four rows of $18 \mathrm{~m}$ length with 25 plants; one row of each side was used as windbreak and border, and $2 \mathrm{~m}$ at the beginning and at the end of the two central rows were avoided, leaving two rows with $14 \mathrm{~m}$ of useful area for evaluations - about 40 useful coffee plants in each plot.

An airblast sprayer (ARBO 360, Montana ${ }^{\circledR}$ ) was used to apply the treatments. The sprayer was coupled to a tractor (Massey Ferguson 4 x 2, Model 265E, $47.8 \mathrm{~kW}$ power, $65 \mathrm{hp}$ ) and has six nozzle ports in each of the bows, totaling 12 port nozzles; the polyethylene spray tank has 300 L capacity, pump with $40 \mathrm{~L} \mathrm{~min}^{-1}$ flow, manual control of sessions and nineblade fan of fixed angle with $0.615 \mathrm{~m}$ of diameter.

The spray nozzles used in the test were hollow cone, ceramic made, with an angle of $80^{\circ}$, commonly positioned for the Brazilian coffee plantations. Five model of MAG tips $\left(\right.$ Magnojet $^{\circledR}$ ) were used (models: 02, 03, 04, 05, 06) to obtain the respective application rates $\left(200,300,400,600,800 \mathrm{~L} \mathrm{ha}^{-1}\right)$ evaluated. According to the manufacturer, those tips produce fine droplet spectrum. To obtaining the necessary spray flow for each application rate, the working pressure was regularly adjusted and ranged from 413 to $620 \mathrm{kPa}$.

To adjust the sprayer, initially, the tractor engine rotation necessary was determined for $540 \mathrm{rpm}$ in the power take - a digital tachometer was used (MDT 2238A, Minipa ${ }^{\circledR}$ ) to verify the correct rpm. The tractor worked at a fixed engine speed of $1900 \mathrm{rpm}$, operating in 1st gear simple, developing a speed of $6.2 \mathrm{~km} \mathrm{~h}^{-1}$ for all treatments, which was compatible with the study area.

A digital thermo-hydro-anemometer (4000, Kestrel $\left.{ }^{\circledR}\right)$ was used to measure the weather conditions at the application of each treatment, to meet the criteria of the good agricultural

Table 1: Description of the coffee areas studied in the present study. Uberlândia, 2017.

\begin{tabular}{cccccc}
\hline \multirow{2}{*}{ Areas } & Coffee cultivars & Age (years) & \multicolumn{3}{c}{ Coffee canopy volume $-\left(\mathrm{m}^{3} \mathrm{ha}^{-1}\right)$} \\
\cline { 4 - 6 } & Topázio MG 1190 & 11 & Maturation & Post-harvest & Filling \\
\hline TRV - -2 & Catuaí vermelho IAC 99 & 15 & 10.230 & 8.572 & 9.375 \\
TRV - 3 & Topázio MG 1190 & 11 & 16.453 & 9.241 & 10.398 \\
\hline
\end{tabular}


practice of pesticide application. The wind speed, as well as air temperature and relative humidity during the applications of each treatment, was assessed (Table 2).

In May, July and December - corresponding to the three coffee phenological stages evaluated - all coffee leaves of three plants in each pre-selected plot were manually harvested and weighed. Thus, the average leaf mass, the plant canopy volume $\left(\mathrm{m}^{3} \mathrm{ha}^{-1}\right)$ and the plant population per hectare were used to determine the leaf density of each plot (Equation 2) and (Table 3).

$$
D=\frac{M}{(T R V+N)}
$$

where:

D: leaf density ( $\mathrm{kg} \mathrm{m}^{-3}$ plant canopy);

$\mathrm{M}$ : leaf mass per plant $(\mathrm{kg})$;

TRV: tree-row volume $\left(\mathrm{m}^{3} \mathrm{ha}^{-1}\right)$; and,

$\mathrm{N}$ : number of plants per hectare (plants ha ${ }^{-1}$ ).

A marker (food colouring - Food, Drug and Cosmetic: FD\&C Blue no.1, bright blue) at the dose of $0.3 \mathrm{~kg} \mathrm{ha}^{-1}$ was added to all spray solutions to be latter detected by absorbance in a spectrophotometer.

The deposition evaluation used ten leaves collected in three plant canopy thirds at the two central lines and aleatory sampled. The first pair of leaves from the orthotropic branches inside the plant canopy was collected and packed in plastic bags separately for each plant third. The bags were stored in a thermal container and later taken to the laboratory for analysis.

To check the spray solution losses to the soil Petri dishes were positioned on the soil and under the coffee canopy of the useful plot (middle of the two central lines) at $0.2 \mathrm{~m}$ from the plant stem. The bottom $\left(0.014 \mathrm{~m}^{2}\right)$, and the cover $\left(0.016 \mathrm{~m}^{2}\right)$ of the Petri dish were aleatorily arranged in the area of each useful parcel. The plates were parallel to the coffee planting line. After the passage of the sprayer, the dishes were collected, packed in plastic bags and stored in a thermal container and later taken to the laboratory for marker analysis.

In the laboratory, the solutions used to wash the samples (leaves and Petri dishes) were analyzed in a spectrophotometer (Biospectro SP-22), using a wavelength of $630 \mathrm{~nm}$ (Silva; Cunha; Nomelini, 2014). The area of the coffee leaves was measured with a bench meter (3100C Area Meter, LI-COR ${ }^{\circledR}$ ). Calibration curves obtained with standard solutions were used to determine the marker concentration $\left(\mathrm{mg} \mathrm{L}^{-1}\right)$ based on the absorbance reading. The initial concentration of the spray solution and the volume of dilution of samples were used to estimate the mass of the marker retained on the coffee leaves and in Petri dishes collected in each parcel. The total deposit was divided by the total leaf area and the area of the Petri

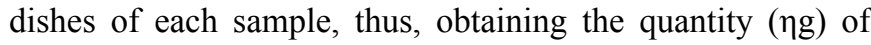
marker per $\mathrm{cm}^{2}$.

Table 2: Average weather conditions of tests of spray deposition on coffee leaves for each phenological stage and canopy volume. Uberlândia, 2017.

\begin{tabular}{|c|c|c|c|c|}
\hline \multirow{2}{*}{ Phenological stages } & \multirow{2}{*}{$\begin{array}{c}\text { TRV } \\
\left(\mathrm{m}^{3} \mathrm{ha}^{-1}\right)\end{array}$} & \multicolumn{3}{|c|}{ Meteorological conditions } \\
\hline & & Temperature $\left({ }^{\circ} \mathrm{C}\right)$ & Wind speed $\left(\mathrm{km} \mathrm{h}^{-1}\right)$ & Air RH (\%) \\
\hline \multirow{3}{*}{ Maturation } & $1-10.230$ & 27.1 & 3.6 & 56.5 \\
\hline & $2-12.453$ & 26.2 & 4.4 & 57.6 \\
\hline & $3-16.200$ & 25.3 & 4.2 & 55.6 \\
\hline \multirow{3}{*}{ Post-harvest } & $1-8.572$ & 21.2 & 6.1 & 55.2 \\
\hline & $2-9.241$ & 20.7 & 3.1 & 58.2 \\
\hline & $3-11.622$ & 22.2 & 4.4 & 53.9 \\
\hline \multirow{3}{*}{ Filling } & $1-9.375$ & 29.3 & 3.6 & 50.1 \\
\hline & $2-10.398$ & 28.0 & 3.9 & 54.2 \\
\hline & $3-13.212$ & 27.1 & 5.1 & 71.2 \\
\hline
\end{tabular}

RH: relative humidity.

Table 3: Coffee leaf density obtained for each plant phenological stage. Uberlândia, 2017.

\begin{tabular}{ccccc}
\hline \multirow{2}{*}{ Plots } & \multicolumn{3}{c}{ Leaf density $\left(\mathrm{kg} \mathrm{m}^{-3}\right.$ of canopy) } & \multirow{2}{*}{ Plants per hectare } \\
\cline { 2 - 4 } & Maturation & Post-harvest & Filling & 4.082 \\
TRV - 1 & 1.181 & 0.881 & 1.803 & 4.082 \\
TRV - 2 & 1.084 & 0.571 & 2.449 & 4.082 \\
TRV - 3 & 1.208 & 0.477 & 3.148 & 4 \\
\hline
\end{tabular}


The data of spray deposition and losses to the soil were used to determine the IVs. Using Equation 3, the VI for each treatment were calculated and correlated with the values of leaf deposition and losses to the soil. The average spray deposition per plant was used considering the three-thirds of the plant. Thus, the VI that provided the largest leaf deposition and the smallest loss to the soil was selected for the different stages of coffee development.

$$
V I=\frac{Q \times 1000}{T R V}
$$

where:

VI: volume index (L $\left.1000 \mathrm{~m}^{-3}\right)$;

Q: rate of application $\left(\mathrm{L} \mathrm{ha}^{-1}\right)$; and

TRV: tree-row volume $\left(\mathrm{m}^{3} \mathrm{ha}^{-1}\right)$.

For the statistical analyzes, the individual analyzes of variance (ANOVA) were initially performed, considering each TRV separately for each application time using the statistical program SISVAR version 5.7 (Ferreira, 2014). Subsequently, a joint analysis of variance (after completed the homogeneity of variances treatment, i.e., $F \leq 7$, through the division of the largest average square of the residue (QMR) and the lower QMR), in 3 x 5 factorial scheme was performed, being three TRV and five application rates. When differences in the effects of treatments were observed by $F$ test $(\mathrm{p}<0.05)$, the Tukey test was used $(\mathrm{p}<0.05)$ to compare the TRV, and regression analysis for the factor 'application rate' in each of the three coffee phenological stages of development. All adjustments of regressions were conducted with SigmaPlot software, version 12.0 (Systat Software Inc.).

\section{RESULTS}

\subsection{Deposition at maturation stage}

There was no interaction between the factors coffee canopy volume and application rate for the spray deposition on leaves (Table 4). In general, the largest TRV (16.200 $\left.\mathrm{m}^{3} \mathrm{ha}^{-1}\right)$ caused the smallest deposit of spray solution. The intermediate vegetative volume $\left(12.453 \mathrm{~m}^{3} \mathrm{ha}^{-1}\right)$ provided the largest deposits of spray solution in all different thirds.

The amount of spray solution deposited on leaves of the internal region of the coffee canopy, except for the upper third, increased with the increase of the application rates above $400 \mathrm{~L} \mathrm{ha}^{-1}$. However, the application rate of $200 \mathrm{~L} \mathrm{ha}^{-1}$ presented similar deposition to the $800 \mathrm{~L} \mathrm{ha}^{-1}$, or even higher in the middle and lower third of the coffee plant canopy, as demonstrated in Figure 1.

\subsection{Deposition at post-harvest stage}

The interaction between the factors TRV and application rate was significant for the deposition on the leaves of the upper and lower third of the coffee canopy, indicating a dependency between them. It should be noted that, in general, the largest TRV was linked with the largest deposits spray

Table 4: Tracer deposition ( $\mathrm{ng} \mathrm{\textrm {cm } ^ { - 2 }}$ ) in the canopy of the coffee plants in the phenological stage of maturation, depending on the application rate and TRV. Uberlândia, 2019.

\begin{tabular}{|c|c|c|c|c|c|c|c|c|c|}
\hline \multirow{4}{*}{$\begin{array}{l}\text { Application rate } \\
\qquad\left(\mathrm{L} \mathrm{ha}^{-1}\right)\end{array}$} & \multicolumn{3}{|c|}{ Upper canopy third } & \multicolumn{3}{|c|}{ Middle canopy third } & \multicolumn{3}{|c|}{ Lower canopy third } \\
\hline & \multicolumn{3}{|c|}{${ }^{1} \mathrm{TRV}\left(\mathrm{m}^{3} \mathrm{ha}^{-1}\right)$} & \multicolumn{3}{|c|}{${ }^{1} \mathrm{TRV}\left(\mathrm{m}^{3} \mathrm{ha}^{-1}\right)$} & \multicolumn{3}{|c|}{${ }^{1} \operatorname{TRV}\left(\mathrm{m}^{3} \mathrm{ha}^{-1}\right)$} \\
\hline & 10.230 & 12.453 & 16.200 & 10.230 & 12.453 & 16.200 & 10.230 & 12.453 & 16.200 \\
\hline & \multicolumn{9}{|c|}{ Deposition $\left(\eta \mathrm{g} \mathrm{cm}^{-2}\right)$} \\
\hline 200 & 597.2 & 670.2 & 547.2 & 724.4 & 833.2 & 706.6 & 603.8 & 750.0 & 682.0 \\
\hline 300 & 566.2 & 652.4 & 459.8 & 603.8 & 720.8 & 545.8 & 510.0 & 743.2 & 512.0 \\
\hline 400 & 550.4 & 647.4 & 409.8 & 571.6 & 715.8 & 478.8 & 352.2 & 653.2 & 437.0 \\
\hline 600 & 487.8 & 634.6 & 354.8 & 560.6 & 680.6 & 473.6 & 432.4 & 698.4 & 508.6 \\
\hline 800 & 459.8 & 649.2 & 343.6 & 503.8 & 772.2 & 683.8 & 432.8 & 813.2 & 573.0 \\
\hline \multirow[t]{2}{*}{ Average } & $532.3 \mathrm{~B}$ & $647.2 \mathrm{~A}$ & $423.0 \mathrm{C}$ & $592.8 \mathrm{~B}$ & $744.5 \mathrm{~A}$ & $577.7 \mathrm{~B}$ & $466.2 \mathrm{~B}$ & $731.6 \mathrm{~A}$ & $542.2 \mathrm{~B}$ \\
\hline & \multicolumn{3}{|c|}{$\mathrm{MSD}_{\mathrm{TRV}}=69.12$} & \multicolumn{3}{|c|}{$\mathrm{MSD}_{\mathrm{TRV}}=81.10$} & \multicolumn{3}{|c|}{$\mathrm{MSD}_{\mathrm{TRV}}=96.12$} \\
\hline CV $(\%)$ & \multicolumn{3}{|c|}{18.91} & \multicolumn{3}{|c|}{18.57} & \multicolumn{3}{|c|}{24.22} \\
\hline $\mathrm{F}_{\mathrm{TRV}}$ & \multicolumn{3}{|c|}{$30.78^{*}$} & \multicolumn{3}{|c|}{$15.14^{*}$} & \multicolumn{3}{|c|}{$23.64^{*}$} \\
\hline $\mathrm{F}_{\text {Rate of application }}$ & \multicolumn{3}{|c|}{$3.86^{*}$} & \multicolumn{3}{|c|}{$5.58^{*}$} & \multicolumn{3}{|c|}{$4.07^{*}$} \\
\hline $\mathrm{F}_{\mathrm{TRV} * \text { Rate of application }}$ & \multicolumn{3}{|c|}{$0.63^{\mathrm{ns}}$} & \multicolumn{3}{|c|}{$1.23^{\mathrm{ns}}$} & \multicolumn{3}{|c|}{$1.45^{\mathrm{ns}}$} \\
\hline
\end{tabular}

${ }^{1}$ Averages followed by the same letter, uppercase in the line, inside each canopy third do not differ by Tukey test ( $\left.p<0.05\right)$. MSD ${ }_{\text {TRV }}$ minimum significant difference to Tree-Row Volume (TRV). CV (\%): coefficient of variation. *significance set at $p<0.05$. ns: non-significant. $F_{\text {TRV }}$, $F_{\text {Rate of }}$ application, $\mathrm{F}_{\mathrm{TRV}}{ }^{*}$ Rate of application $\mathrm{F}$ value for TRV, application rate and the interaction between TRV and application rate, respectively. 
solution (Table 5); however, there was no difference for the highest application rate in the upper third of the coffee canopy. There was no interaction between the factors for the middle third of the coffee canopy (Table 5). The lower TRV $\left(8.572 \mathrm{~m}^{-3}\right.$ $\left.\mathrm{ha}^{-1}\right)$ provided the lowest spray solution deposition.

The spray deposition on the leaves of the coffee canopy, independently of the plant position (lower, middle or upper third), in general, decreased with the increase of the application rate. The application rate interferes on the quality of the spray applications, as shown in Figure 2.

\subsection{Deposition at grain filling stage}

In the upper third of the coffee plant canopy, the interaction between the factors canopy volume and application

Upper Canopy Third

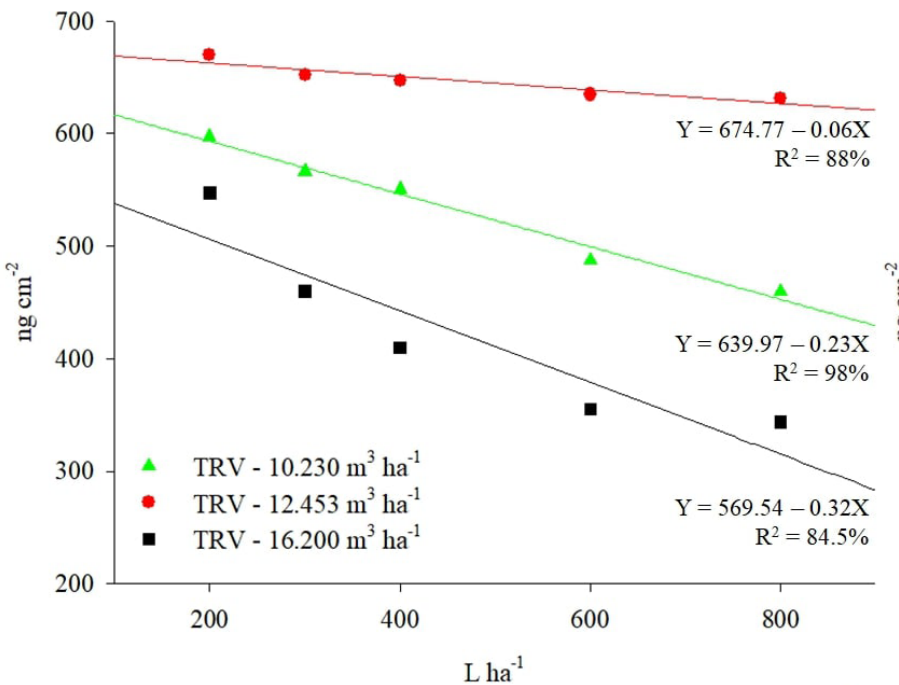

rate was significant for the spray deposition (Table 6). The largest vegetative volume $\left(13.212 \mathrm{~m}^{3} \mathrm{ha}^{-1}\right)$ provided the smallest deposits of spray solution. The lowest TRV $\left(9.375 \mathrm{~m}^{3}\right.$ $\mathrm{ha}^{-1}$ ) observed generated the largest spray solution deposits, in the middle canopy third (Table 6), with the exception of the 300 $\mathrm{L} \mathrm{ha}^{-1}$ rate of application. There was no interaction between the studied factors (application rate and canopy volume) for the lower third of the coffee canopy (Table 6).

The spray deposition in the internal region of the coffee canopy, independently of the third section considered, in general, decreased with the increase in the application rate until a certain point, then the spray deposition returned to increase. This increase in leaf deposition is evident when using application rates above $600\left(\mathrm{~L} \mathrm{ha}^{-1}\right)$, as shown in Figure 3.

Middle Canopy Third

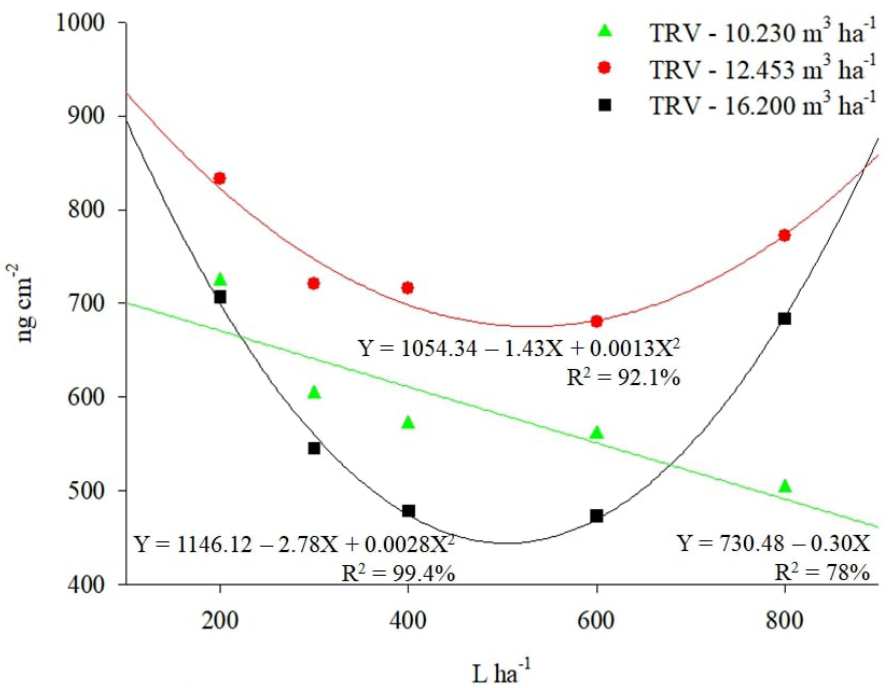

Lower Canopy Third

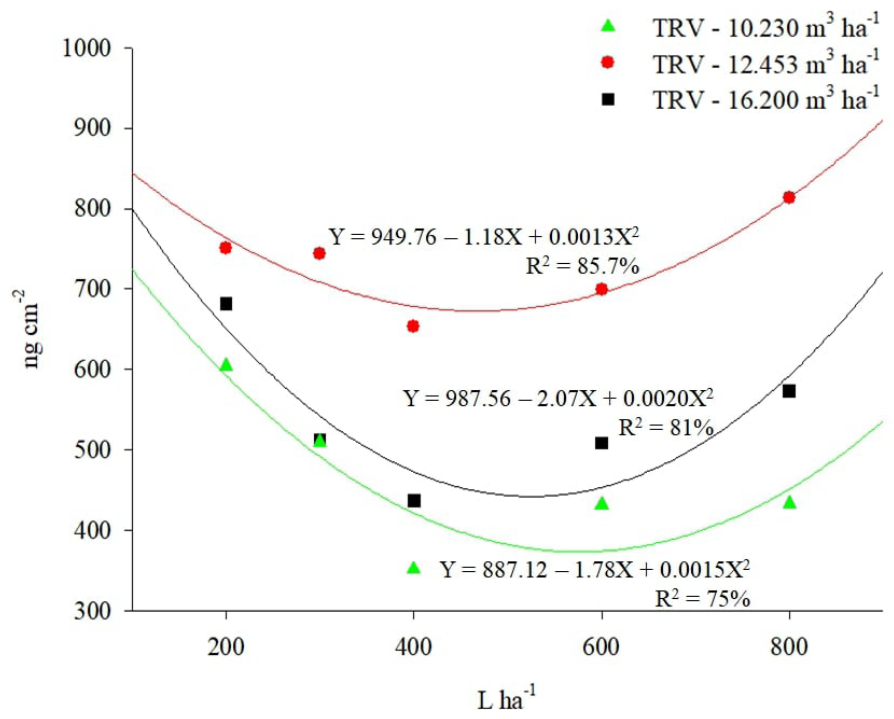

Figure 1: Tracer deposition ( $\mathrm{ng} \mathrm{cm}^{-2}$ ) on coffee leaves depending on the application rate and the canopy volume in the maturation phenological stage. Uberlândia, 2019. 
Table 5: Tracer deposition ( $\mathrm{ng} \mathrm{cm}^{-2}$ ) in the canopy of the coffee plants in the phenological stage of post-harvest, depending on the application rate and TRV. Uberlândia, 2019.

\begin{tabular}{|c|c|c|c|c|c|c|c|c|c|}
\hline \multirow{4}{*}{$\begin{array}{l}\text { Application rate } \\
\qquad\left(\mathrm{L} \mathrm{ha}^{-1}\right)\end{array}$} & \multicolumn{3}{|c|}{ Upper canopy third } & \multicolumn{3}{|c|}{ Middle canopy third } & \multicolumn{3}{|c|}{ Lower canopy third } \\
\hline & \multicolumn{3}{|c|}{${ }^{1} \mathrm{TRV}\left(\mathrm{m}^{3} \mathrm{ha}^{-1}\right)$} & \multicolumn{3}{|c|}{${ }^{1} \mathrm{TRV}\left(\mathrm{m}^{3} \mathrm{ha}^{-1}\right)$} & \multicolumn{3}{|c|}{${ }^{1} \mathrm{TRV}\left(\mathrm{m}^{3} \mathrm{ha}^{-1}\right)$} \\
\hline & 8.572 & 9.241 & 11.622 & 8.572 & 9.241 & 11.622 & 8.572 & 9.241 & 11.622 \\
\hline & \multicolumn{9}{|c|}{ Deposition $\left(\eta \mathrm{g} \mathrm{cm}^{-2}\right)$} \\
\hline 200 & $528.4 \mathrm{~B}$ & $680.2 \mathrm{~B}$ & $1089.8 \mathrm{~A}$ & 700.4 & 1057.0 & 1241.0 & $862.2 \mathrm{~B}$ & $910.6 \mathrm{~B}$ & $1219.4 \mathrm{~A}$ \\
\hline 300 & $454.4 \mathrm{~B}$ & $646.2 \mathrm{~B}$ & $1028.8 \mathrm{~A}$ & 1104.8 & 925.6 & 1336.4 & $847.0 \mathrm{~B}$ & $948.0 \mathrm{~B}$ & $1630.4 \mathrm{~A}$ \\
\hline 400 & $394.4 \mathrm{~B}$ & $573.6 \mathrm{~B}$ & $935.8 \mathrm{~A}$ & 741.8 & 797.0 & 1319.6 & $777.0 \mathrm{~B}$ & $909.0 \mathrm{~B}$ & $1535.0 \mathrm{~A}$ \\
\hline 600 & $465.6 \mathrm{~B}$ & $616.6 \mathrm{~B}$ & $902.0 \mathrm{~A}$ & 600.8 & 783.4 & 1151.6 & $743.8 \mathrm{~B}$ & $810.6 \mathrm{~B}$ & $1478.4 \mathrm{~A}$ \\
\hline 800 & $625.0 \mathrm{~A}$ & $532.0 \mathrm{~A}$ & $691.8 \mathrm{~A}$ & 543.4 & 689.4 & 1025.0 & $710.4 \mathrm{~B}$ & $665.8 \mathrm{~B}$ & $1220.0 \mathrm{~A}$ \\
\hline \multirow[t]{2}{*}{ Average } & & & & $688.8 \mathrm{C}$ & $850.5 \mathrm{~B}$ & $1214.7 \mathrm{~A}$ & & & \\
\hline & \multicolumn{3}{|c|}{$\mathrm{MSD}_{\mathrm{TRV}}=256.83$} & \multicolumn{3}{|c|}{$\mathrm{MSD}_{\mathrm{TRV}}=125.47$} & \multicolumn{3}{|c|}{$\mathrm{MSD}_{\mathrm{TRV}}=225.98$} \\
\hline CV $(\%)$ & \multicolumn{3}{|c|}{24.77} & \multicolumn{3}{|c|}{19.98} & \multicolumn{3}{|c|}{14.48} \\
\hline $\mathrm{F}_{\mathrm{TRV}}$ & \multicolumn{3}{|c|}{$45.3^{*}$} & \multicolumn{3}{|c|}{$53.9 *$} & \multicolumn{3}{|c|}{$136.2^{*}$} \\
\hline $\mathrm{F}_{\text {Rate of application }}$ & \multicolumn{3}{|c|}{$1.9^{\mathrm{ns}}$} & \multicolumn{3}{|c|}{$6.2 *$} & \multicolumn{3}{|c|}{$6.7 *$} \\
\hline $\mathrm{F}_{\mathrm{TRV} V^{*} \text { Rate of application }}$ & \multicolumn{3}{|c|}{$2.1^{*}$} & \multicolumn{3}{|c|}{$0.8^{\mathrm{ns}}$} & \multicolumn{3}{|c|}{$2.5^{*}$} \\
\hline
\end{tabular}

${ }^{1}$ Averages followed by the same letter, uppercase in the line, inside each canopy third do not differ by Tukey test $(p<0.05)$. MSD $\mathrm{TRV}: \mathrm{minimum}$ significant difference to Tree-Row Volume (TRV). CV (\%): coefficient of variation. *significance set at $p<0.05$. ns: non-significant. $F_{T R V}$, $F_{\text {Rate of }}$ application, $\mathrm{F}_{\mathrm{TRV}}{ }^{*}$ Rate of application $\mathrm{F}$ value for TRV, application rate and the interaction between TRV and application rate, respectively.
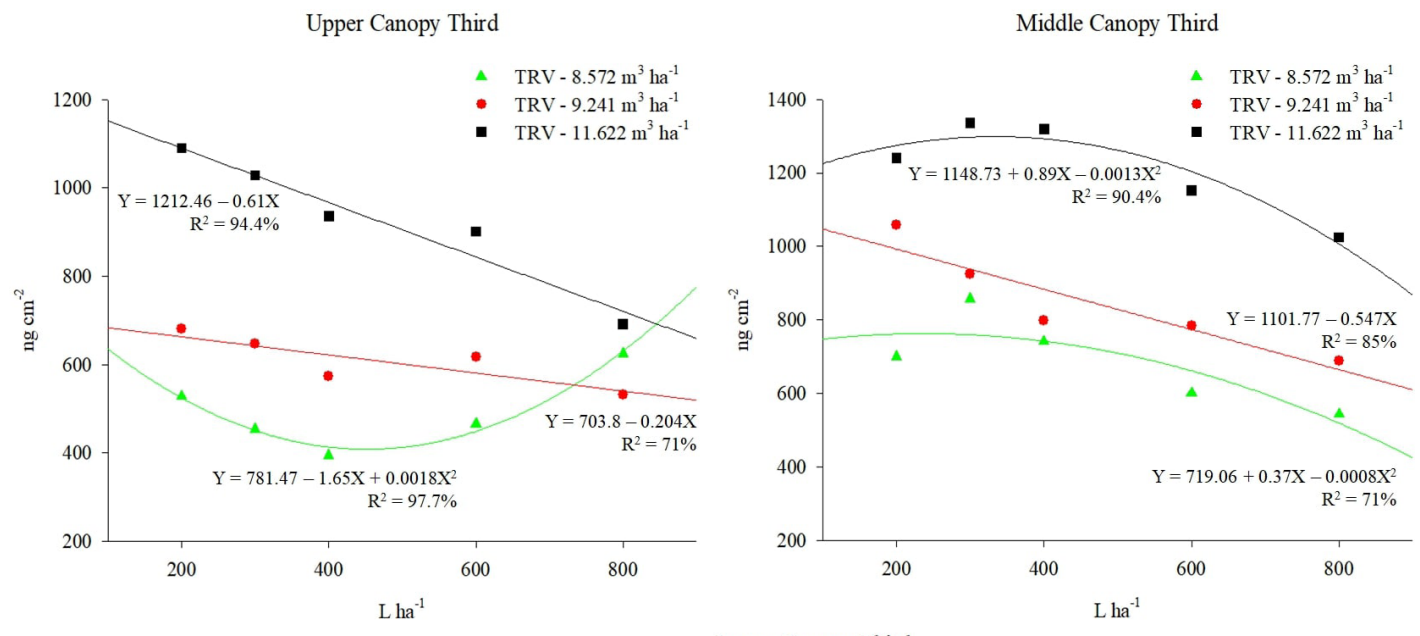

Lower Canopy Third

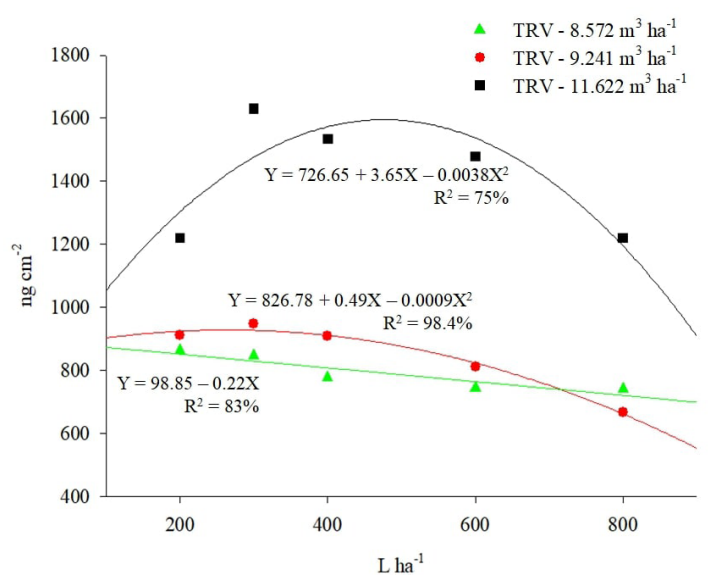

Figure 2: Tracer deposition $\left(\mathrm{ng} \mathrm{cm}^{-2}\right)$ on coffee leaves depending on the application rate and the canopy volume in the postharvest phenological stage. Uberlândia, 2019. 
Table 6: Tracer deposition ( $\mathrm{ng} \mathrm{cm}^{-2}$ ) in the canopy of the coffee plants in the phenological stage of grain filling, depending on the application rate and TRV. Uberlândia, 2019.

\begin{tabular}{|c|c|c|c|c|c|c|c|c|c|}
\hline \multirow{4}{*}{$\begin{array}{l}\text { Application rate } \\
\qquad\left(\mathrm{L} \mathrm{ha}^{-1}\right)\end{array}$} & \multicolumn{3}{|c|}{ Upper canopy third } & \multicolumn{3}{|c|}{ Middle canopy third } & \multicolumn{3}{|c|}{ Lower canopy third } \\
\hline & \multicolumn{3}{|c|}{${ }^{1} \mathrm{TRV}\left(\mathrm{m}^{3} \mathrm{ha}^{-1}\right)$} & \multicolumn{3}{|c|}{${ }^{1} \mathrm{TRV}\left(\mathrm{m}^{3} \mathrm{ha}^{-1}\right)$} & \multicolumn{3}{|c|}{${ }^{1} \mathrm{TRV}\left(\mathrm{m}^{3} \mathrm{ha}^{-1}\right)$} \\
\hline & 9.375 & 10.398 & 13.212 & 9.375 & 10.398 & 13.212 & 9.375 & 10.398 & 13.212 \\
\hline & \multicolumn{9}{|c|}{ Deposition $\left(\eta \mathrm{g} \mathrm{cm}^{-2}\right)$} \\
\hline 200 & $1,294 \mathrm{~A}$ & $868.8 \mathrm{~B}$ & $693.0 \mathrm{~B}$ & $424.0 \mathrm{~B}$ & $417.2 \mathrm{~B}$ & $578.6 \mathrm{~A}$ & 485.0 & 535.0 & 513.0 \\
\hline 300 & $945.2 \mathrm{~A}$ & $885.0 \mathrm{~A}$ & $548.0 \mathrm{~B}$ & $527.4 \mathrm{~A}$ & $386.6 \mathrm{~A}$ & $506.6 \mathrm{~A}$ & 383.2 & 455.0 & 397.4 \\
\hline 400 & $891.6 \mathrm{~A}$ & $1055.0 \mathrm{~A}$ & $508.8 \mathrm{~B}$ & $537.2 \mathrm{~A}$ & $317.6 \mathrm{~B}$ & $431.2 \mathrm{AB}$ & 294.8 & 375.4 & 297.4 \\
\hline 600 & $826.6 \mathrm{~A}$ & $823.4 \mathrm{~A}$ & $455.0 \mathrm{~B}$ & $600.4 \mathrm{~A}$ & 268.6B & $380.0 \mathrm{~B}$ & 326.0 & 232.2 & 299.0 \\
\hline 800 & $669.6 \mathrm{~B}$ & $929.2 \mathrm{~A}$ & $422.4 \mathrm{C}$ & $740.0 \mathrm{~A}$ & $294.4 \mathrm{C}$ & 463.0B & 390.4 & 392.2 & 319.0 \\
\hline \multirow[t]{2}{*}{ Average } & & & & & & & $375.9 \mathrm{~A}$ & $398.0 \mathrm{~A}$ & $365.2 \mathrm{~A}$ \\
\hline & \multicolumn{3}{|c|}{$\mathrm{MSD}_{\mathrm{TRV}}=239.23$} & \multicolumn{3}{|c|}{$\mathrm{MSD}_{\mathrm{TRV}}=152.13$} & \multicolumn{3}{|c|}{$\mathrm{MSD}_{\mathrm{TRV}}=86.41$} \\
\hline CV $(\%)$ & \multicolumn{3}{|c|}{19.85} & \multicolumn{3}{|c|}{21.7} & \multicolumn{3}{|c|}{33.26} \\
\hline $\mathrm{F}_{\mathrm{TRV}}$ & \multicolumn{3}{|c|}{$52.8 *$} & \multicolumn{3}{|c|}{$33.5^{*}$} & \multicolumn{3}{|c|}{$0.4^{\mathrm{ns}}$} \\
\hline $\mathrm{F}_{\text {Rate of application }}$ & \multicolumn{3}{|c|}{$7.4^{*}$} & \multicolumn{3}{|c|}{$1.8^{\mathrm{ns}}$} & \multicolumn{3}{|c|}{$7.2^{*}$} \\
\hline $\mathrm{F}_{\mathrm{TRV} V^{*} \text { Rate of application }}$ & \multicolumn{3}{|c|}{$3.7^{*}$} & \multicolumn{3}{|c|}{$4.9^{*}$} & \multicolumn{3}{|c|}{$0.5^{\mathrm{ns}}$} \\
\hline
\end{tabular}

${ }^{1}$ Averages followed by the same letter, uppercase in the line, inside each canopy third do not differ by Tukey test $(p<0.05)$. MSD $\mathrm{TRV}: \mathrm{minimum}$ significant difference to Tree-Row Volume (TRV). CV (\%): coefficient of variation. *significance set at $p<0.05$. ns: non-significant. $F_{\text {TRV }}, F_{\text {Rate of }}$ application, $\mathrm{F}_{\mathrm{TRV}}{ }^{*}$ Rate of application $\mathrm{F}$ value for TRV, application rate and the interaction between TRV and application rate, respectively.

Upper Canopy Third

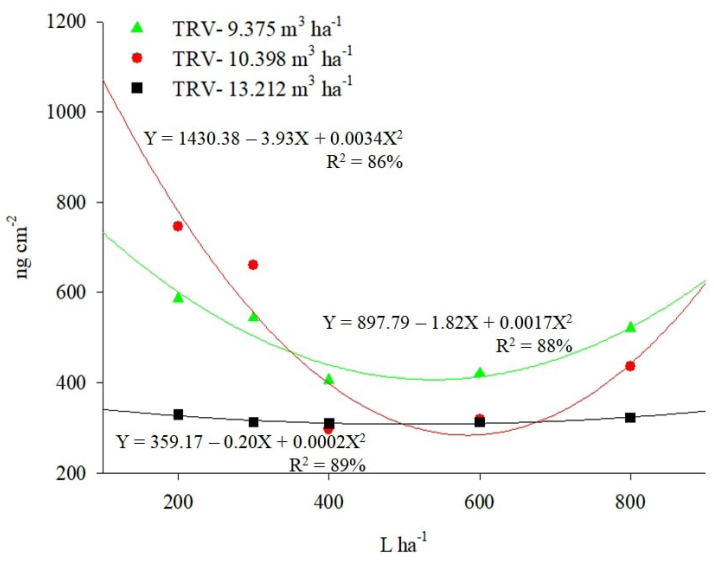

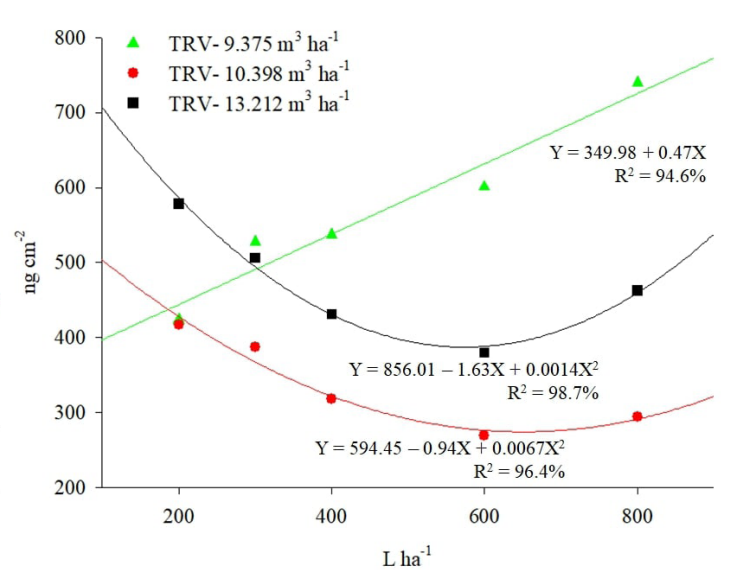

Lower Canopy Third

Middle Canopy Third

TRV $-9.375 \mathrm{~m}^{3} \mathrm{ha}^{-1}$

- TRV- $10.398 \mathrm{~m}^{3} \mathrm{ha}^{-1}$

- TRV- $13.212 \mathrm{~m}^{3} \mathrm{ha}^{-1}$

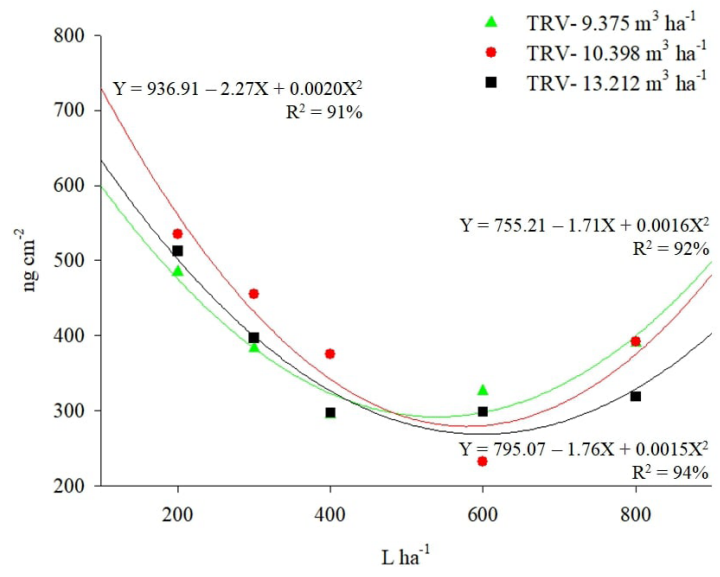

Figure 3: Tracer deposition ( $\mathrm{ng} \mathrm{cm}^{-2}$ ) on coffee leaves depending on the application rate and the canopy volume in the grain filling phenological stage. Uberlândia, 2019. 


\subsection{Spray losses to the soil}

There was no interaction between the factors application rate and canopy volume for spray solution losses to the soil in different phenological stages of the coffee crop (Table 7). The greatest losses to the soil (Petri dishes) were observed with the largest TRV (16.200 and $\left.11.622 \mathrm{~m}^{3} \mathrm{ha}^{-1}\right)$, in the maturation and post-harvest coffee phenological stages, respectively (Table 7).

The spray deposition on the Petri dishes, independently of the coffee phenological stages and TRV, generally increased with the increase of the application rate, as demonstrated in Figure 4. The application rates of 200 and $300 \mathrm{~L} \mathrm{ha}^{-1}$, in general, presented low losses to the soil and high spray deposition in the coffee canopy, highlighting the ability to increase leaf coverage, to reduce the outflow of crop inputs and to reduce environmental risks.

\subsection{Volume index (VI) determination}

The use of the Tree-Row Volume method requires knowledge of VI, which corresponds to the volume necessary to effectively cover one cubic meter of the canopy of the plant. Thus, knowing the factors application rate and TRV allowed the calculation of VI using Equation 3 (Table 8). Then, the graphs relating VI to the variables spray deposition and losses to the soil were plotted. However, it was not possible to establish significant mathematical models, given the performance of the data (Figure 5).

The volumes of the coffee canopy, in this study, ranged from 8.572 to $16.200 \mathrm{~m}^{3} \mathrm{ha}^{-1}$ at different phenological stages of the coffee crop development, and the VI ranged from 12.3

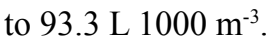

The leaf deposition in the canopy and the spray solution losses to the soil for each coffee phenological stage indicated the volume index (VI) appropriate to each situation. The VI was adjusted to allow high plant wetting and small loss by runoff to the soil.

In the period of grain ripening (maturation), a VI of

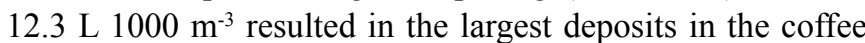
canopy with a minor loss of spray solution to the soil. In the post-harvest stage, the spray deposition on the canopy has tended to increase with the VI increase; however, the losses to

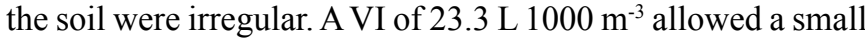
loss of spray solution. In the grain filling stage, a VI of $15.1 \mathrm{~L}$ $1000 \mathrm{~m}^{-3}$ resulted in the largest deposits in the coffee canopy with a minor loss of spray solution to the soil.

\section{DISCUSSION}

\subsection{Deposition at maturation stage}

The largest vegetative volume provided the smallest deposits in the different positions of the coffee plants. This result can be explained by the fact that there is a great overlap of plagiotropic branches and leaves, forming a barrier to the spray solution penetration in the canopy (Matta et al., 2007). This result corroborates with the study conducted by Mewes et al. (2011), where the density, architecture and canopy height

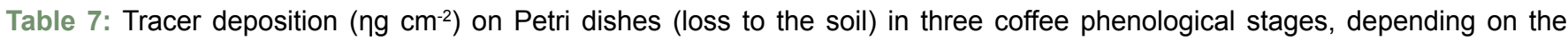
application rate and TRV. Uberlândia, 2019.

\begin{tabular}{|c|c|c|c|c|c|c|c|c|c|}
\hline \multirow{4}{*}{$\begin{array}{l}\text { Application rate } \\
\qquad\left(\mathrm{L} \mathrm{ha}^{-1}\right)\end{array}$} & \multicolumn{3}{|c|}{ Maturation } & \multicolumn{3}{|c|}{ Post-harvest } & \multicolumn{3}{|c|}{ Grain filling } \\
\hline & \multicolumn{3}{|c|}{${ }^{1} \mathrm{TRV}\left(\mathrm{m}^{3} \mathrm{ha}^{-1}\right)$} & \multicolumn{3}{|c|}{${ }^{1} \mathrm{TRV}\left(\mathrm{m}^{3} \mathrm{ha}^{-1}\right)$} & \multicolumn{3}{|c|}{${ }^{1} \mathrm{TRV}\left(\mathrm{m}^{3} \mathrm{ha}^{-1}\right)$} \\
\hline & 10.230 & 12.453 & 16.200 & 8.572 & 9.241 & 11.622 & 9.375 & 10.398 & 13.212 \\
\hline & \multicolumn{9}{|c|}{ Petri dishes deposition $\left(\eta \mathrm{g} \mathrm{cm}^{-2}\right)$} \\
\hline 200 & 334.6 & 610.6 & 497.4 & 1063.8 & 1219.4 & 2285.50 & 1063.8 & 1010.2 & 735.4 \\
\hline 300 & 483.0 & 770.0 & 747.4 & 1568.1 & 1228.6 & 2393.21 & 1568.0 & 1211.2 & 751.4 \\
\hline 400 & 683.6 & 846.2 & 1061.8 & 1800.5 & 1467.3 & 2465.39 & 1800.4 & 1325.8 & 972.8 \\
\hline 600 & 737.0 & 1057.0 & 1071.6 & 1754.9 & 1624.9 & 2569.55 & 1915.0 & 1282.2 & 1085.8 \\
\hline 800 & 856.8 & 1426.2 & 1104.6 & 1916.4 & 1994.2 & 2592.35 & 1916.4 & 1344.8 & 1320.8 \\
\hline \multirow[t]{2}{*}{ Average } & $942.0 \mathrm{~A}$ & $619.0 \mathrm{~B}$ & $896.6 \mathrm{~A}$ & 1620.7B & $1506.8 \mathrm{~B}$ & $2461.2 \mathrm{~A}$ & $1652.7 \mathrm{~A}$ & $1234.8 \mathrm{~B}$ & $973.2 \mathrm{C}$ \\
\hline & \multicolumn{3}{|c|}{$\mathrm{MSD}_{\mathrm{TRV}}=253.96$} & \multicolumn{3}{|c|}{$\mathrm{MSD}_{\mathrm{TRV}}=363.78$} & \multicolumn{3}{|c|}{$\mathrm{MSD}_{\mathrm{TRV}}=229.76$} \\
\hline CV $(\%)$ & \multicolumn{3}{|c|}{45.31} & \multicolumn{3}{|c|}{28.54} & \multicolumn{3}{|c|}{26.09} \\
\hline $\mathrm{F}_{\mathrm{TRV}}$ & \multicolumn{3}{|c|}{$5.54^{*}$} & \multicolumn{3}{|c|}{$24.03^{*}$} & \multicolumn{3}{|c|}{$26.04^{*}$} \\
\hline $\mathrm{F}_{\text {Rate of application }}$ & \multicolumn{3}{|c|}{$6.92^{*}$} & \multicolumn{3}{|c|}{$3.23^{*}$} & \multicolumn{3}{|c|}{$7.28^{*}$} \\
\hline $\mathrm{F}_{\mathrm{TRV} * \text { Rate of application }}$ & \multicolumn{3}{|c|}{$0.40^{\mathrm{ns}}$} & \multicolumn{3}{|c|}{$0.44^{\mathrm{ns}}$} & \multicolumn{3}{|c|}{$0.95^{\mathrm{ns}}$} \\
\hline
\end{tabular}

${ }^{1}$ Averages followed by the same letter, uppercase in the line, inside each canopy third do not differ by Tukey test $(p<0.05)$. MSD $D_{\text {TRV }}$ minimum significant difference to Tree-Row Volume (TRV). CV (\%): coefficient of variation. *significance set at $p<0.05$. ns: non-significant. $F_{\text {TRV }}, F_{\text {Rate of }}$ application, $\mathrm{F}_{\mathrm{TRV}}{ }^{*}$ Rate of application $\mathrm{F}$ value for TRV, application rate and the interaction between TRV and application rate, respectively. 
reduced the spray deposition on eucalyptus by the 'wall effect' of the leaves in the canopy.

The intermediate vegetative volume provided the largest deposits of spray solution regarding the different coffee canopy thirds. This is possibly due to the density of $1.084 \mathrm{~kg} \mathrm{~m}^{-3}$ plant $^{-1}$, as shown in Table 3. This greater deposition on low density can be attributed to the lowest amount of leaves, i.e., less overlap among them, increasing the spray solution deposition per unit leaf area (Souza; Velini; Palladini, 2007). Souza Júnior et al. (2017) found that coffee leaf density of $1 \mathrm{~kg} \mathrm{~m}^{-3}$ presented higher leaf depositions than the coffee leaf densities of 1.5 and 2 $\mathrm{kg} \mathrm{m}^{-3}$, reinforcing the data obtained in the present study.

The application rate is also a factor that interferes with the quality of the applications. Fernandes, Ferreira and Oliveira (2010) concluded that the deposition in the lower third of coffee plants was increased with the increase in the application rate within the range of 250 to $700 \mathrm{~L} \mathrm{ha}^{-1}$, reinforcing the results observed in the present study.

In the upper third, there was a reduction of the spray solution deposition with the increase of the rate of application. This was possibly caused by the redistribution and outflow of the spray solution to the lower parts of the coffee plant canopy. Gitirana Neto et al. (2016) observed that the increase in the application rate from 200 to $400 \mathrm{~L} \mathrm{ha}^{-1}$ did not generate increments of spray solution deposition in the upper third of coffee canopy. Vitória et al. (2018) observed similar deposition in the upper third when application rates varied between 498 and $782 \mathrm{~L} \mathrm{ha}^{-1}$. It must be highlighted that the upper third of the coffee canopy is the furthest part to the spray nozzles, challenging the deposition of plant protection products on the target, which may help to explain the results obtained.
Maturation

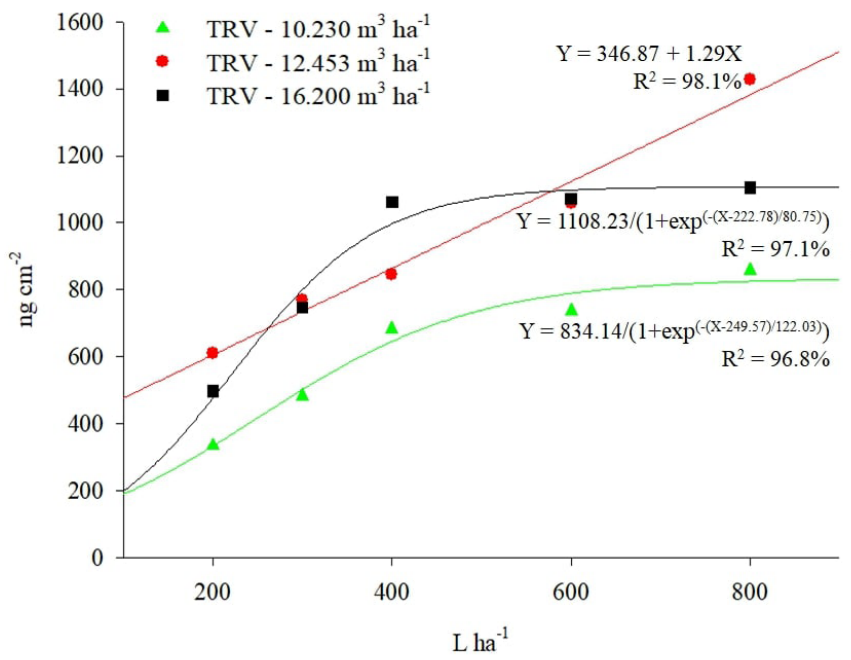

Post-harvest

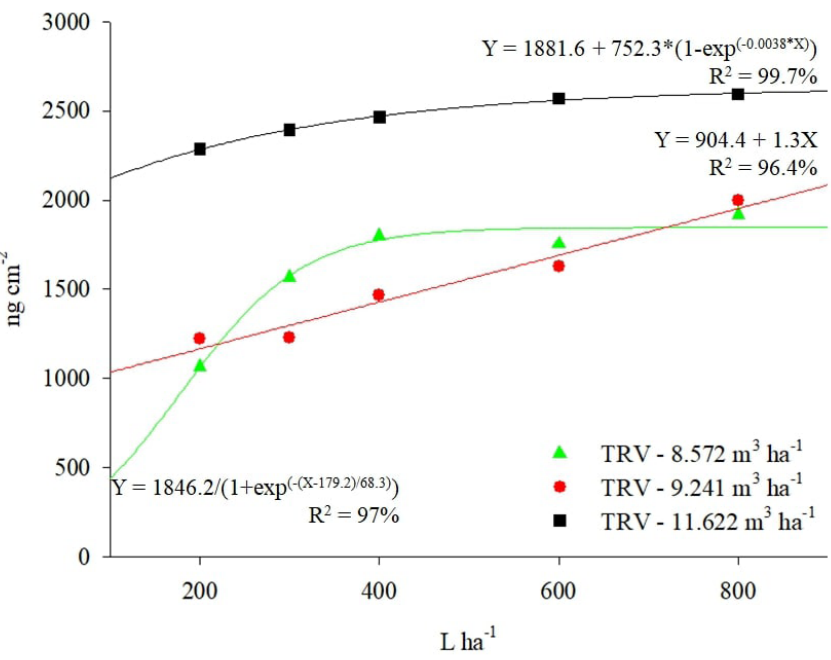

Grain filling

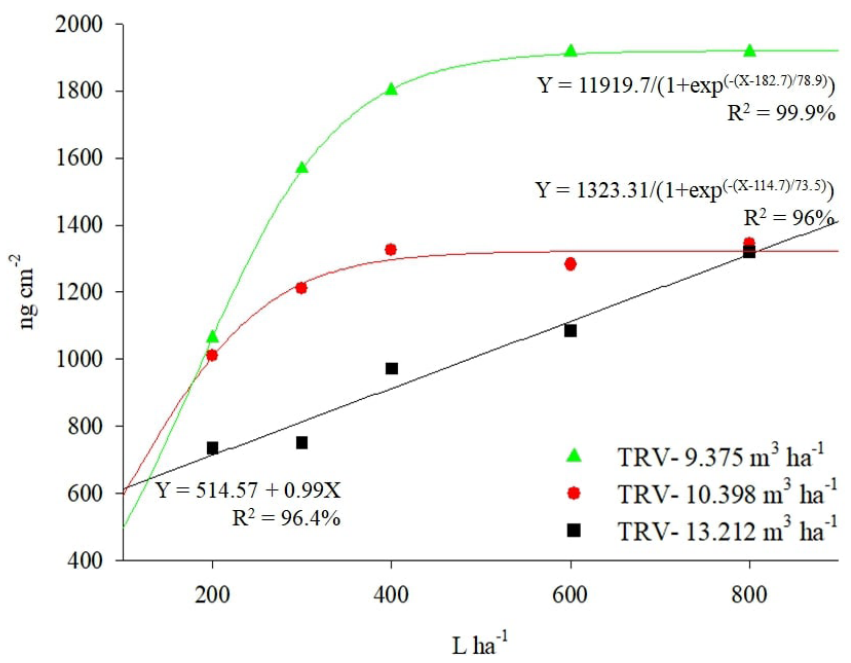

Figure 4: Tracer deposition ( $\mathrm{ng} \mathrm{cm}^{-2}$ ) on Petri dishes (loss to the soil) depending on the application rate and the coffee canopy volume in different phenological stages. Uberlândia, 2019. 
Table 8: Spray volume indexes (VI) calculated for the application conditions studied. Uberlândia, 2019.

\begin{tabular}{|c|c|c|c|c|}
\hline \multirow{3}{*}{ Phenological stage } & \multirow{3}{*}{$\begin{array}{l}\text { Application rate } \\
\qquad\left(\mathrm{L} \mathrm{ha}^{-1}\right)\end{array}$} & \multicolumn{3}{|c|}{ TRV } \\
\hline & & $1^{*}$ & $2^{* *}$ & $3^{* * *}$ \\
\hline & & $10.230\left(\mathrm{~m}^{3} \mathrm{ha}^{-1}\right)$ & $12.453\left(\mathrm{~m}^{3} \mathrm{ha}^{-1}\right)$ & $16.200\left(\mathrm{~m}^{3} \mathrm{ha}^{-1}\right)$ \\
\hline & & \multicolumn{3}{|c|}{$V I\left(\mathrm{~L} 1000 \mathrm{~m}^{-3}\right)$} \\
\hline \multirow{5}{*}{ Maturation } & 200 & 19.5 & 16.0 & 12.3 \\
\hline & 300 & 29.3 & 24.0 & 18.5 \\
\hline & 400 & 39.1 & 32.1 & 24.7 \\
\hline & 600 & 58.6 & 48.2 & 37.0 \\
\hline & \multirow[t]{3}{*}{800} & 78.2 & 64.2 & 49.4 \\
\hline \multirow{7}{*}{ Post-harvest } & & $8.572\left(\mathrm{~m}^{3} \mathrm{ha}^{-1}\right)$ & $9.241\left(\mathrm{~m}^{3} \mathrm{ha}^{-1}\right)$ & $11.622\left(\mathrm{~m}^{3} \mathrm{ha}^{-1}\right)$ \\
\hline & & \multicolumn{3}{|c|}{$V I\left(\mathrm{~L} 1000 \mathrm{~m}^{-3}\right)$} \\
\hline & 200 & 23.3 & 21.6 & 17.2 \\
\hline & 300 & 34.9 & 32.4 & 25.8 \\
\hline & 400 & 46.6 & 43.3 & 34.4 \\
\hline & 600 & 70.0 & 64.9 & 51.6 \\
\hline & \multirow[t]{3}{*}{800} & 93.3 & 86.5 & 68.8 \\
\hline \multirow{7}{*}{ Grain filling } & & $9.375\left(\mathrm{~m}^{3} \mathrm{ha}^{-1}\right)$ & $10.398\left(\mathrm{~m}^{3} \mathrm{ha}^{-1}\right)$ & $13.212\left(\mathrm{~m}^{3} \mathrm{ha}^{-1}\right)$ \\
\hline & & \multicolumn{3}{|c|}{$V I\left(\mathrm{~L} 1000 \mathrm{~m}^{-3}\right)$} \\
\hline & 200 & 21.3 & 19.2 & 15.1 \\
\hline & 300 & 32.0 & 28.8 & 22.7 \\
\hline & 400 & 42.6 & 38.5 & 30.3 \\
\hline & 600 & 64.0 & 57.7 & 45.4 \\
\hline & 800 & 85.3 & 76.9 & 60.5 \\
\hline
\end{tabular}

* 1 - Topázio MG 1190 coffee cultivar; ** 2 - Catuaí Vermelho IAC 99 coffee cultivar; ${ }^{* * *} 3$ - Topázio MG 1190 coffee cultivar.

\subsection{Deposition at post-harvest stage}

The largest vegetative volume provided the largest spray deposits in the different thirds of the coffee plant. The reduction of leaf density at the post-harvest stage is due to the defoliation caused by the mechanical harvest of coffee grains (Santinato et al., 2014). This great deposition in the lower leaf density (Table 3), again, can be attributed to the small number of leaves, i.e., less overlap of the leaves and plagiotropic branches. This result corroborates with the findings observed by Souza et al. (2017) while studying the influence of the canopy characteristics in the distribution of spray solution in coffee plants. The authors found great coverage of the coffee plant in low leaf densities. Another factor that can also increase the spray deposit per unit leaf area is the plant architecture (Souza; Velini; Palladini, 2007).

As previously reported, Fernandes, Ferreira and Oliveira (2010) concluded that the deposition in the lower third of coffee plants increased with the increase of the application rate in the range between 250 and $700 \mathrm{~L} \mathrm{ha}^{-1}$. However, this was not observed in this study. This may have occurred due to the foliage density differences, as demonstrated in the present study, which interferes in the spray solution deposition. Another factor that helps to explain the difference refers to the fact that the tracer has been used in the same concentration for different application rates, which tends to overestimate the deposits at higher rates. In the present study, it was used the same dose, to represent what occurs in the field, when you change the application rate, with the maintenance of the dose of application.

The lowest application rates (200 and $\left.300 \mathrm{~L} \mathrm{ha}^{-1}\right)$, in general, resulted in high spray deposits demonstrating the ability to increase leaf coverage. The reduction in the application rate has been discussed for the coffee crop production (Decaro Júnior et al., 2014; Fernandes; Ferreia; Oliveira, 2010; Miranda et al., 2012). According to Viana et al. (2010), this could be possible and can result in a uniform distribution of droplet diameter and density, achieving success with the low application rate.

According to Decaro Júnior et al. (2015), the use of application rates around $400 \mathrm{~L} \mathrm{ha}^{-1}$ did not bring benefits to the spray deposition in coffee plants concerning the $200 \mathrm{~L} \mathrm{ha}^{-1}$, confirming the results obtained in the present study.

\subsection{Deposition at grain filling stage}

The largest vegetative volume provided the smallest deposits in the upper canopy third. The lowest spray solution 
deposition was observed for the largest TRV, possibly due to the high leaf density (Table 3 ). Another concern that may explain this lowest deposition is the fact that the plants had high stature in relation to the sprayer and, consequently, the distance from the spray nozzles to the upper third of the plants was also greater. As a result, the droplets sprayed become more subject to losses, and may evaporate or be carried by the wind, causing less deposition (Alvarenga et al., 2014).
In the middle canopy third, the lowest TRV resulted the largest spray deposits. The nozzle proximity to the middle third of the coffee canopy can help to explain these results. Another point that can make clear this high deposition is the low leaf density which was lower than the TRV from other thirds (Table 3). The high deposition with the low leaf density can be attributed to the fact that there is a small number of leaves, i.e., less overlap among branches and leaves (Souza; Velini; Palladini, 2007).
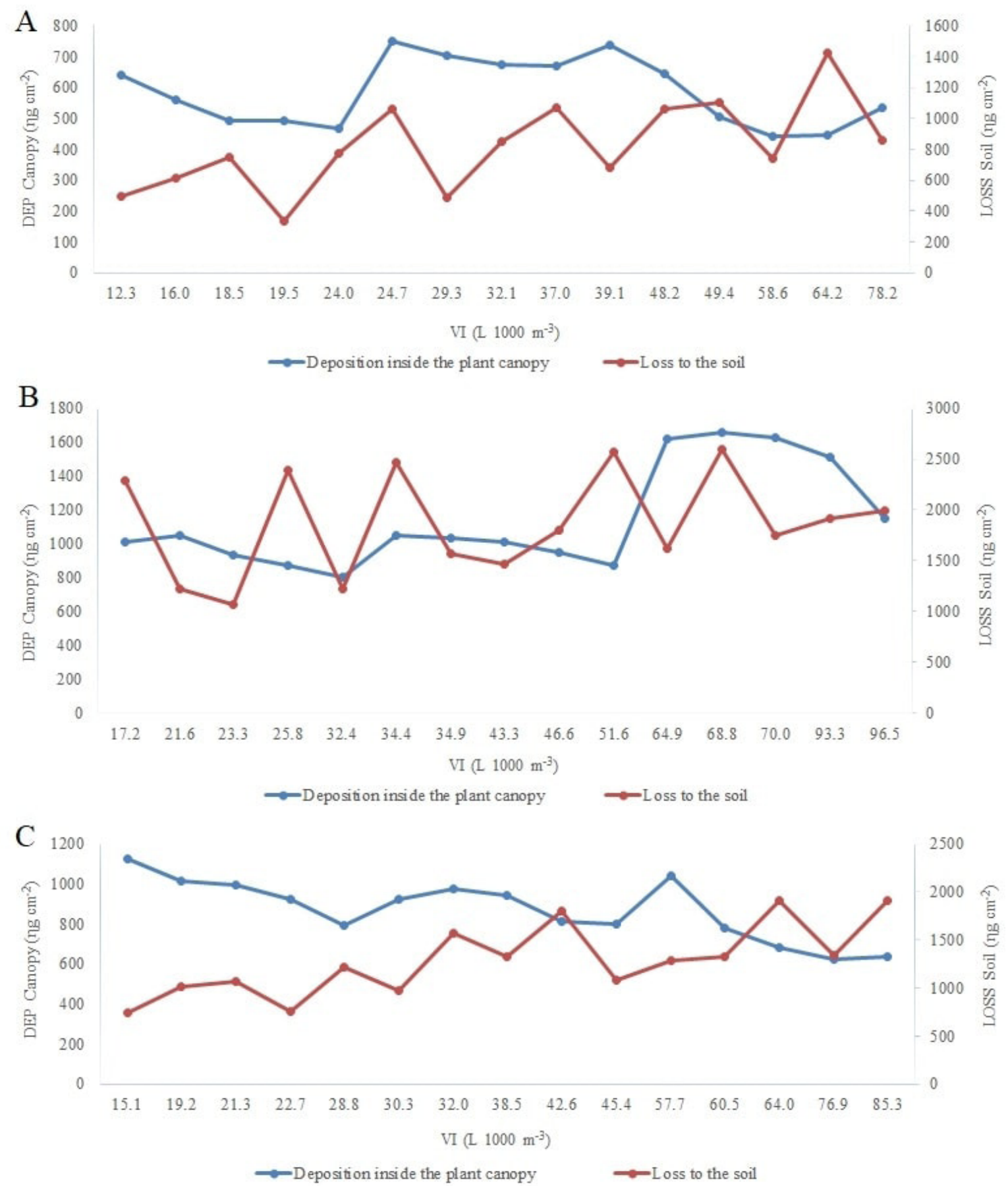

Figure 5: Spray deposition in coffee canopy $\left(\mathrm{ng} \mathrm{cm}^{-2}\right)$ and loss to the soil $\left(\mathrm{ng} \mathrm{cm}^{-2}\right)$ as function of the volume index (VI) for coffee cultivation at the maturation (A), post-harvest (B) and grain filling (C) phenological stages. Uberlândia, 2019. 
For the lower third, no TRV differences were detected when analyzing the tracer deposition on leaves. These results corroborate the data obtained by Miranda et al. (2012), and Silva, Cunha and Nomelini (2014).

Concerning application rate, lower values increased spray deposition. Many attempts have been made to reduce the pesticide application rates, aiming to reduce costs, environmental contamination and to maintain or increase the efficiency of spray application. Increasing spray efficiency also improves the operational capacity of the sprayers, enabling the work to be carried out in larger areas under more favourable meteorological conditions (Decaro Júnior et al., 2014).

\subsection{Spray losses to the soil}

Spray losses to the soil were studied by deposition on Petri dishes located on the ground, under the projection area of the coffee canopy. The largest spray losses happened with the great vegetative volume. The variations of leaf densities also have a direct influence on penetration and deposition of pesticides on coffee (Silva; Cunha; Nomelini, 2014; Souza Júnior et al., 2017). The reduction of leaf density at the postharvest stage is due to the defoliation caused by the mechanical harvest of coffee grains (Santinato et al., 2014), and to seasonal variations that occur as a function of water availability and temperature variations (Emilio et al., 2008; Matta et al., 2007).

The correct application rate to reach the needs for leaf wetness with minimal spray losses to the soil requires studies to enable and optimize the pesticide application, mainly for tree crops (Alves; Cunha, 2014; Souza Júnior et al., 2017). The excess of spray solution that the leaf does not holds falls and contribute to soil contamination (Silva; Leite; Ferreira, 2008).

According to Vitória et al. (2018), the loss of spray solution to the soil was equivalent for application rates between 498 and $782 \mathrm{~L} \mathrm{ha}^{-1}$. This result demonstrates a trend that was also observed in the present study of the losses stabilization at high volumes of spray solution.

In general, the spraying using application rates above $400 \mathrm{~L} \mathrm{ha}^{-1}$ was not consistent with the criteria of good agricultural practices, in addition to increasing the operational costs (Decaro Júnior et al., 2014; Miranda et al., 2012).

\subsection{Volume index (VI) determination}

The coffee canopy volume influenced the spray deposit on the coffee leaves; therefore, this volume needs to be considered in the definition of application rates in coffee cultivation. However, an exact relationship between leaf deposition and canopy volume was not found. Larger canopy volumes are tied to higher deposition of the spray solution on the leaves in some cases, but in other cases they are linked to lower deposition. In many situations, the leaf density often helps to explain this relationship and should be considered in the definition of the application rates. The determination of the TRV alone may not always lead to the best results of leaf deposition; it is also necessary to know the foliage density.

The measurement of the coffee canopy volume in the field is relatively simple; however, the same is not true for the leaf density, whose assessment is time-consuming. In this way, new methods to define the leaf density need to be developed to provide a determination more practical and feasible.

\section{CONCLUSIONS}

The canopy volume and the leaf density should be considered together to define the application rate for coffee crop protection.

It is possible to reduce the application rate of pesticides to volumes close to $200 \mathrm{~L} \mathrm{ha}^{-1}$, with deposition increments under some operational conditions in the coffee cultivation and reduction of losses to the soil.

Volume indexes were defined for different coffee phenological stages to allow proper wetting of the coffee plant canopy and a reduction in losses to the soil.

\section{ACKNOWLEDGEMENTS}

The authors would like to thank FAPEMIG (Research Foundation of the State of Minas Gerais), CNPq (National Council of Scientific and Technological Development) and CAPES (Coordination for the Improvement of Higher Education Personnel) for the financial support.

\section{REFERENCES}

ALVARENGA, C. A. et al. Air and liquid volumetric distribution in vertical in a hydropneumatic sprayer.

Applied Research \& Agrotechnology, 7(1):71-79, 2014.

ALVES, G. S.; CUNHA, J. P. A. R. Field data and prediction models of pesticide spray drift on coffee crop. Pesquisa Agropecuária Brasileira, 49(8):622-629, 2014.

BYERS, R. E.; HICKEY, K. D.; HILL, C. H. Base gallonage per acre. Virginia Fruit 60:19-23, 1971.

CHEN, Y. et al. Spray Deposition inside tree canopies from a newly developed variable-rate air-assisted sprayer. Transactions of the ASABE, 56(6):1263-1272, 2013.

COPETTI, L. S.; CORONEL, D. A. Transmissão da variação da taxa de câmbio para os preços de exportação brasileiros do café robusta: um estudo comparativo do dólar e do euro. Revista Capital Científico, 18(1):24-44, 2020.

CUNHA, J. P. A. R.; GITIRANA NETO, J.; BUENO, M. R. Evalution of a device for the application of pesticides on mechanized coffee crops (Coffea arabica L.) Interciênia, 36(4):312-316, 2011. 
DECARO JÚNIOR, S. T. et al. Reducing spray volume for the control of (Lepidoptera: Lyonetiidae) in coffee plants. Coffee Science, 10(4):491-498, 2015.

DECARO JÚNIOR, S. T. et al. Relationship among variables of sprays applied at reduced volumes in a coffee plantation. Aspects of Applied Biology, 122:415-422, 2014.

EMILIO, S. K. et al. Variação sazonal do potencial da água nas folhas de cafeeiro em Mococa, SP, Bragantia, 67(2):421-428, 2008.

EMPRESA BRASILEIRA DE PESQUISA GROPECUÁRIA - EMBRAPA. Sistema Brasileiro de Classificação de Solo. 3 ed. Brasília, 2013. 353 p.

FERNANDES, A. P.; FERREIRA, M. C.; OLIVEIRA, C. A. L. Eficiência de diferentes ramais de pulverização e volumes de calda no controle de Brevipalpus phoenicis na cultura do café. Revista Brasileira de Entomologia, 54(1):130-135, 2010.

FERREIRA, D. F. Sisvar: Um guia dos seus procedimentos de comparações múltiplas Bootstrap. Ciência e Agrotecnologia, 38(2):109-112, 2014.

FERREIRA, M. C.; LEITE, G. J.; LASMAR, O. Cobertura e depósito de calda fitossanitária em plantas de café pulverizadas com equipamento original e adaptado para plantas altas. Bioscience Journal, 29(1):1539-1548, 2013.

GIL, E. et al. Variable rate application of plant protection products in vineyard using ultrasonic sensors. Crop Protection, 26(8):1287-1297, 2007.

GITIRANA NETO, J. et al. Deposição de calda promovida por pulverizadores empregados na cafeicultura de montanha. Coffee Science, 11(2):267-275, 2016.

KÖPPEN, W.; GEIGER, R. Klimate der Erde. Gotha: Verlag Justus Perthes, 1928.

MATIELLO, J. B. et al. Cultura de café no Brasil: Novo manual de recomendações. Rio de Janeiro e Varginha: MAPA/PROCAFÉ, 2010. 542p.

MATTA, F. M. et al. Ecophysiology of coffee growth and production. Brazilian Journal Plant Physiology, 19(4):485-510, 2007.

MEWES, W. L. C. et al. Deposição de calda em eucalipto, utilizando pulverização pneumática. Bioscience Journal, 27(2):283-288, 2011.

MiNGUELA, J. V.; CUNHA, J. P. R. A. Manual de aplicação de produtos fitossanitários. Viçosa: Aprenda Fácil, 2010. 588p.
MIRANDA, G. R. B. et al. Avaliação dos depósitos da pulverização em frutos de cafeeiro utilizando dois equipamentos associados a diferentes taxas de aplicação.

Revista Agrogeoambiental, 4(1):15-20, 2012.

MIRANDA-FUENTES, A. et al. Assessing the optimal liquid volume to be sprayed on isolated olive trees according to their canopy volumes. Science of The Total Environment, 568:296-305, 2016.

NASCIMENTO, L. M.; SPEHAR, C. R.; SANDRI, D. Produtividade de cafeeiro orgânico no cerrado após a poda sob diferentes regimes hídricos. Coffee Science, 9(3):354-365, 2014.

SÁNCHEZ-HERMOSILLA, J. et al. Volume application rate adapted to the canopy size in greenhouse tomato crops. Scientia Agrícola, 70(6):390-396, 2013.

SANTINATO, F. et al Colheita mecanizada do café em lavouras de primeira safra. Revista Brasileira de Engenharia Agrícola e Ambiental, 19(12):1215-1219, 2015.

SANTINATO, F. et al. Análise quali-quantitativa da operação de colheita mecanizada de café em duas safras. Coffee Science, 9(4):495-505, 2014.

SCAPIN, M. S. et al. Tree-row-volume-based sprays of copper bactericide for control of citrus canker. Crop Protection, 77:119-126, 2015.

SILVA, A. R.; LEITE, M. T.; FERREIRA, M. C. Estimativa da área foliar e capacidade de retenção de calda fitossanitária em cafeeiro. Bioscience Journal, 24(3):66-73, 2008.

SILVA JÚNIOR, G. J. et al. Spray volume and fungicide rates for citrus black spot control based on tree canopy volume. Crop Protection, 85:38-45, 2016.

SILVA, J. E. R.; CUNHA, J. P. A. R.; NOMELINI, Q. S. $\mathrm{S}$. Deposição de calda em folhas de cafeeiro e perdas para o solo com diferentes taxas de aplicação e pontas de pulverização. Revista Brasileira de Engenharia Agrícola e Ambiental, 18(12):1302-1306, 2014.

SOUSA JÚNIOR, J. M. et al. Determinação do índice de volume de pulverização para a cultura do café. Coffee Science, 12(1):82-90, 2017.

SOUZA JÚNIOR, J. M. et al. Influência da densidade foliar na distribuição de calda no dossel do cafeeiro (Coffea arabica L.). Coffee Science, 12(2):216-222, 2017.

SOUZA, R. T.; VELINI, E. D.; PALLADINI, L. A. Aspectos metodológicos para análise de depósitos de pulverizações pela determinação dos depósitos pontuais. Planta Daninha, 25(1):195- 202, 2007. 
SUTTON, T. B.; UNRATH, C. R. Evaluation of the tree-rowvolume model for full season pesticide application on apples. Plant Disease, 72(7):629-632, 1988.

TACHIBANA, A.; ANTUNIASSI, U. R. Avaliação de sistemas de aplicação de defensivos para a citricultura. Energia na Agricultura, 23(1):1-17, 2008 .
VIANA, R. G. et al. Distribuição volumétrica e espectro de gotas de pontas de pulverização de baixa deriva. Planta Daninha, 28(2):439-446, 2010.

VITÓRIA, E. L. et al. Pulverização hidropneumática usando equipamentos com e sem assistência eletrostática em cafeeiro Conilon. Revista Engenharia na Agricultura, 26(3):217-228, 2018. 